\title{
皮膚表皮に存在するカルシウム依存性タンパク質 架橋酵素の発現之活性調節機構に関する研究
}

\section{（2002 年度農芸化学奨励賞受賞）}

\author{
人 見 清 隆
}

\section{(名古屋大学大学院生命農学研究科)}

Key words: transglutaminase; skin; epidermis; calpain; slime mold

1. 序: トランスグルタミナーゼの反応機構と高等動 物でのアイソザイム

タンパク質は翻訳された後に, 糖鎖や脂質の付加, リン 酸化，限定分解なよ゙，実際にその機能を果たすためにさま ざまな修飾を受ける場合がある。これらに比べると明らか にされている例はまだ少ないが，自己または他のタンパク 質上の共有結合的な架橋化（タンパク質分解の逆反応）上 いう修飾方式も存在する. タンパク質同士の架橋というこ のユニークな修飾反応を担うのがトランスグルタミナーゼ
（EC 2.3.2.13, 以下 TGase 上略記）之呼ばれる, カルシウ 么依存性の酵素である11,2).

この酵素はタンパク質のグルタミン残基に，同種または 異種のタンパク質のリシン残基とをイソペプチド結合で架 橋させる反応を触媒する. リシン残基の反応部位は $\varepsilon-ア 、$ 八基であるが，リシン残基以外にも一級アミンのアミノ基 屯同様にこの反応に参加しうる（図 1).この反応形式を利 用して，標識された一級アミンの取り込まれる量を指標 に, 酵素活性の測定が可能である ${ }^{31}$. また, 一級アミンが存 在しないとき, 水分子を基質にして, グルタミンからグル タミン酸への変換も生じさせる場合むある，さらにはま た，脂質との間にエステル結合を介在する場合あある゙!
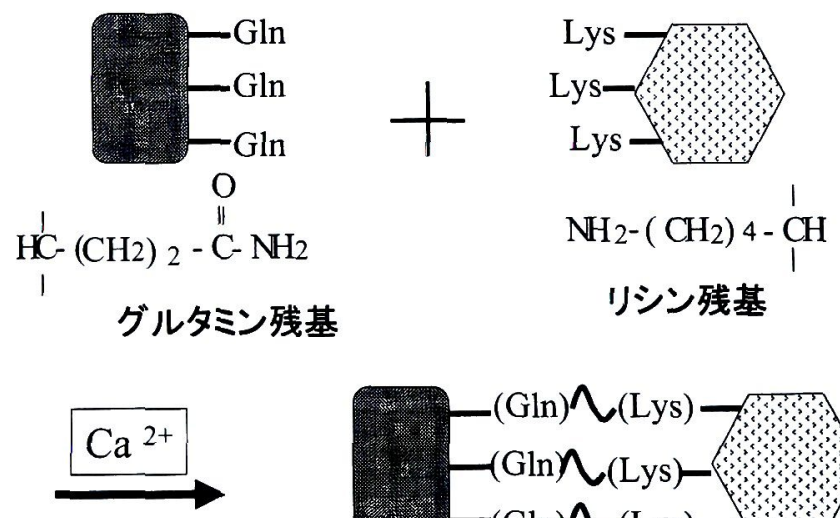

リシン残基
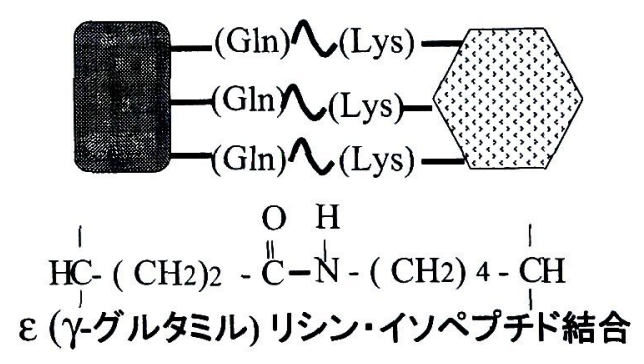

図 1 トランスグルタミナーゼの反応形式

Studies on expression and activation mechanisms of transglutaminase in epidermis

Kiyotaka Hזтом (Department of Applied Molecular Biosciences, Graduate School of Bioagricultural Sciences, Nagoya University) 
表 ヒトトランスグルタミナーゼファミリー

TGase 6 および TGase 7 は遗伝子配列に基づいて分子量が算出されている.

\begin{tabular}{|c|c|c|c|c|}
\hline 名称 & 局在部位 & 分子質量 $(\mathrm{kDa})$ & プロセシング & 生理的役割 \\
\hline Factor XIII & 血小板 & 85 & あり & 血液凝固 \\
\hline TGase 1 & 上皮組織 & $98 \sim 110$ & あり & 支蜀の硬度化 \\
\hline TGase 2 & ほとんどすべて & 77 & なし & $\begin{array}{l}\text { 細胞死, 細胞接着 } \\
\text { 創傷治癒, 骨形成 }\end{array}$ \\
\hline TGase 3 & 表皮, 毛胞 & 77 & あり & 皮鬳の硬度化 \\
\hline TGase 4 & 生殖腺 & 77 & なL & 交尾栓形成（マウス） \\
\hline TGase 5 & 表皮, 血球 & 84 & な & 皮膚の硬度化 \\
\hline TGase $Y(6)$ & $?$ & 79 (推定) & $?$ & $?$ \\
\hline TGase $Z(7)$ & $?$ & 80 (推定) & $?$ & $?$ \\
\hline
\end{tabular}

タンパク質を架橋化重合するというユニークな反応を利用 して，食品成分の架橋（テクスチャーの改変）など産業上 屯幅広く利用されている。

タンパク質同士の架橋反応は, 動物から植物, 微生物ま で幅広い生物に見いだされる．しかしそれを担う酵素の構 造については動物とそれ以外の生物では一次構造に大きな 違いがあり，どの生物がどのような酵素による架橋反応の 触媒活性を有するかは明確になっていない，先に述べた TGase の産業上の利用には，微生物を利用した大量生産に 関する研究が行われている5).

高等動物に打いてはいくつかのアイソザイムが存在し て，それぞれが組織特異的な発現パターンを有する。比 の遺伝子配列情報からは活性欠失型の類似タンパク質（赤 血球 band 4.2) あ含めて 9 種類も存在することがわかっ ている6!.表に現在明らかになっているヒトのアインザイ ムに関する知見を簡単にま之めてある。これらのうちいく つかは，生理的な役割が明確にされているものもあるが， 現在むなお（単に試験管内で架橋させるだけではない生理 学的に意味のある)，基質の検索之その意義の解明につい て多くの研究が進行中である。これらの中で研究が早くか ら進行し，明らかになっているあのとしては，フィブリン を架橋して血液凝固の最終段階にかかわる Factor XIII が ある7!。また細胞死との関連が示されている TGase 2 につ いては, それ以外にも神経系の再生, 細胞外マトリクスの 強化のほか, 本来の架橋酵素活性とは別に, GTP 結合タン パク質や細胞接着因子としてむ役割を果たすことが示され ている81.99. また最近注目を集めているものに，ハンチント ン病やアルッハイマー病などの脳神経系の病気にこの酵素 による余分な架橋産物形成がかかわっているというストー リーが報告されている(10).

このように各アイソザイムについて，その役割がわかり つつある興味ある成果が(これまで酵素としての TGase 研究にかかわらなかった)，さまざまな研究領域のグルー プから報告されてきている，すべてを紹介することはでき
ないので，本稿では皮膚表皮の形成にかかわる二つの TGase (TGase 1, TGase 3) の機能之活性調節機構を中心 にしてまとめたい，また，高等動物のみならず，筆者は外 界に対する生物の表層における防御機構に関心があり，モ デル生物である粘菌 (真性粘菌)の TGase についても研究 を進めて興味ある知見を得ている，進化之の関係も触机つ っここれについても少し述べたいと思う。

2. TGase 1 上T Tase 3 の組換えタンパク質を用い た活性化機構の解析

まず両酵素がその役割を果たす皮膚表皮の形成に関して 述べる，皮膚表皮は，真皮上層の基底細胞が分化と增殖を 繰り这し，順送りに表層へと向加う。このとき，表皮細胞 の分化の過程で細胞内の構造タンパク質（ケラチン，ロリ クリン，インボルクリンなど）か架橋重合して細胞内を裏 打ちする，Cornified Envelope と呼ばれる層が形成され る ${ }^{11 !}$.このときに架橋化を担うのがTGase であり，分化し 表皮に向かうにつれて細胞内で活性化をすると予測されて いる.ただ，この分化段階のどこで両酵素が発現し，限定 分解され，互いがどの上うな基質認識をしているのか（同 じではないことは試験管レベルで明らかになっているが) は不明であった（図2）。

TGase 1 抢よび TGase 3 については，皮膚表皮に存在 するTGase として，元来区別されずにその存在が知られ ていた，それぞれの酵素タンパク質の精製，遺伝子単離に よる構造解析から，この酵素は活性のない前駆体の形で存 在することがわかっていた（その後 TGase 1 は前駆体で あある程度活性を有するというように訂正された ${ }^{12)}$.

TGase 1 はおよそ分子量が 95 110 kDa の前駆体が, 表皮細胞の分化に伴って 10,33, $67 \mathrm{kDa}$ の断片になる. この断片は非共有結合で結合した状態を保っており，この 形が活性化体であるとされていた 13),14)。これは, 血液凝固 因子として働く TGase, Factor XIII の場合に，前駆体型 がトロンビンによる切断を受けて活性化を受けるのと同じ 


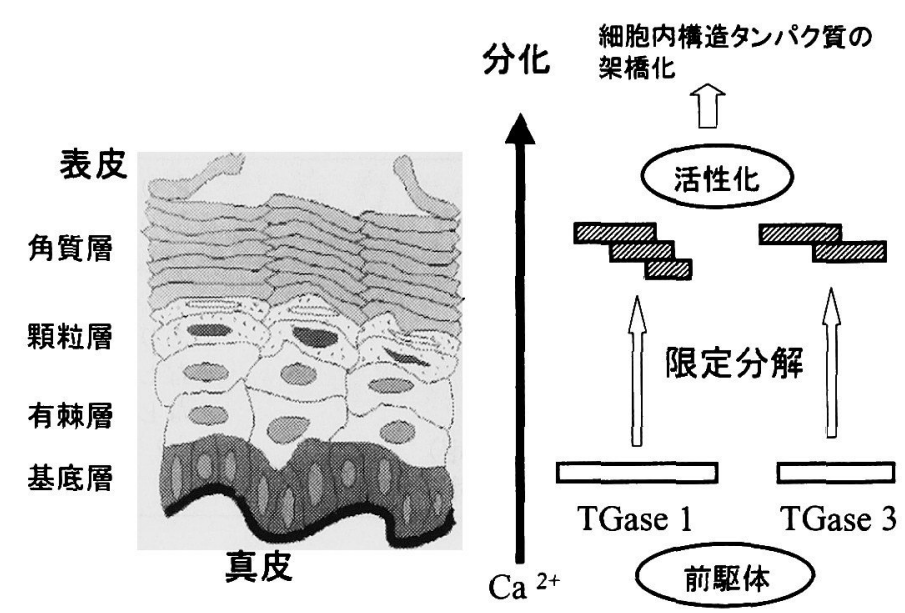

図 2 皮䖉表皮細胞分化とトランスグルタミナーゼの活性化

機構であるとされている.

一方, TGase 3 は $77 \mathrm{kDa}$ の前駆体で合成され，限定分 解によって $47 \mathrm{kDa}$ と $30 \mathrm{kDa}$ の断片となり, やはり両者 が結合した状態で活性をむつことになる15), 16).

これらの酵素については，構造および限定分解による活 性化ということは明らかになったものの，皮膚における存 在量が少ないために，生化学的な性質や活性化のメカニズ ムについては未知な点が多かった，筆者はまず，大腸菌に よる組換え体の産生が不溶性画分となることから，バキュ ロウイルスー昆虫細胞の発現系を用いることとした。この 発現系は，ほぼ天然型と同じ立体構造の組換え体を作製で きる真核細胞のタンパク質の有用な発現系である171 199. これを用いて両タンパク質の組換え体を作製した。ここで も可溶性画分にくる割合は少なかったが，解析に十分な量 の組換えタンパク質を単一に精製した ${ }^{201}$, 21).

これらの組換えタンパクを用いて行ったのは，(1)限定分 解を担う酵素は何か，(2)限定分解してよ゙のように活性化す るか, (3)活性化した後, これに影響を与える因子は何か, という点である. TGase 1 之 TGase 3 之は，共に皮虑表 皮に存在して，その形成に必須であるので性質もよく似て いるかと予想したが，次のように翼なるものであった。

まず，これらの前駆体酵素を切断活性化する酵素につい て検索したところ, カルシウム依存性の細胞内プロテアー ゼであるカルパインが TGase 1 を切断することを見いだ した. また切断された TGase 1 はその前駆体に比べて, カルシウム感受性が上昇していた21). 一方 TGase 3 につ いては, 微生物由来のディスパーゼという酵素では活性化 されるむのの in vivo, in vitro での活性化酵素は不明であ る. TGase 1 を活性化するカルパインの作用も全く受けな い. しかし，筆者は，高濃度カルシウム存在下で TGase 3 前駆体が酵素活性を有するように変化することを見いだし
ている. TGase 3 に特異的なカルシウム結合タンパク質も 見いだされており，限定分解とは異なった活性化機構が存 在するのかもしれない，最近，TGase 3 の立体構造解析が 明らかにされ，前駆体にもカルシウムが結合する部位があ ることが示された ${ }^{22)}$. 活性化された両方の TGase につい て，他のアイソザイムで調べられている制御因子について 検討した. GTP は TGase 2 の活性を阻害することが知ら れている. TGase 1 は活性阻害をしなかったものの TGase 3 は阻害された ${ }^{23)}$. また，一酸化窒素によっても， TGase 2 は活性阻害を受けるが, TGase 1 および TGase 3 はそのような効果は見られなかった。

以上のような活性制御機構を，おおまかにまとめると図 3のようになる.

\section{TGase 3 の発現に関する解析 241.25$)$}

はじめに述べたように, TGase の存在樣式はアイソザイ ムによってかなりその組織分布や細胞内局在を異にしてい る. TGase 1 は皮膚表皮だけでなく，上皮組織にも幅広く 発現していることが報告されている26).一方, TGase 3 に ついてはあまり解析が進んでおらず，筆者らはポリクロー ナル抗体，モノクローナル抗体を作製してこれを検討し た.この際に, TGase はアイソザイムが数多く存在するた めに他のアイソザイムとの交差に注意を払わなければなら ない.

各組織の TGase 3 の存在をマウスの各組織について RT-PCR で調べたところ，皮䖉のほか，胃や小腸にむ存在 することが明らかになった，意外であったのは脳や神経系 の細胞株にも存在することであり，これはヒトの脳でも存

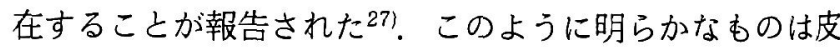
䖉，マウスの前胃で他の組織については存在量が少ないた め，まだタンパク質レベルでの存在意義や，実際の活性化 


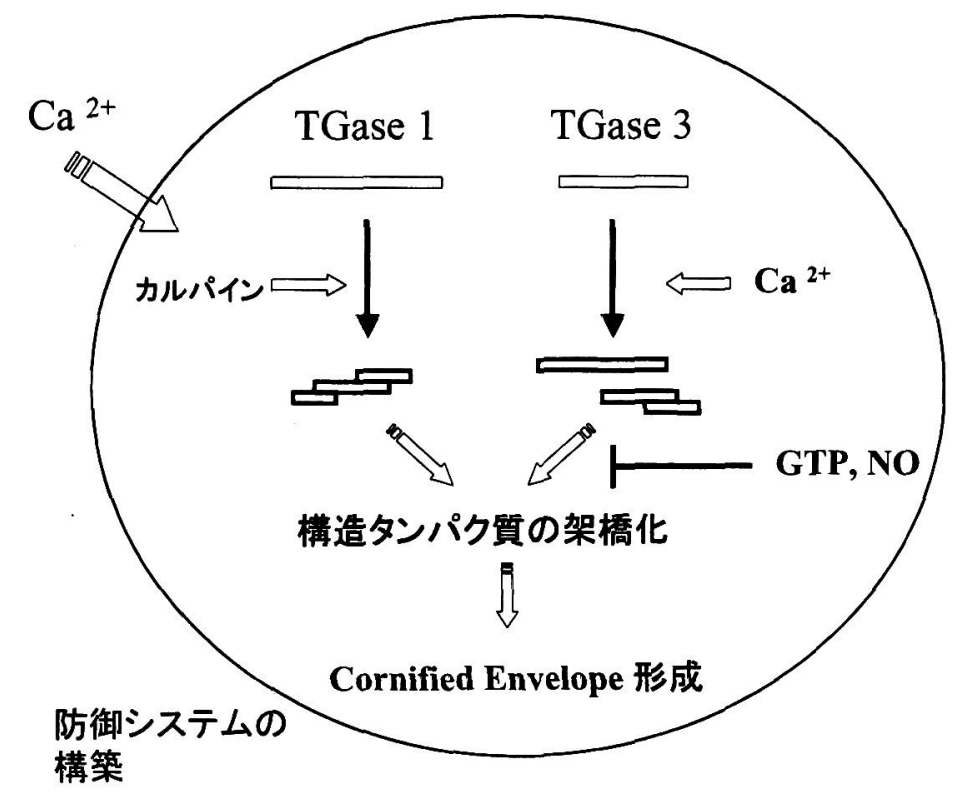

図 3 皮虞表皮細胞でのトランスグルタミナーゼの活性化とその制御機構

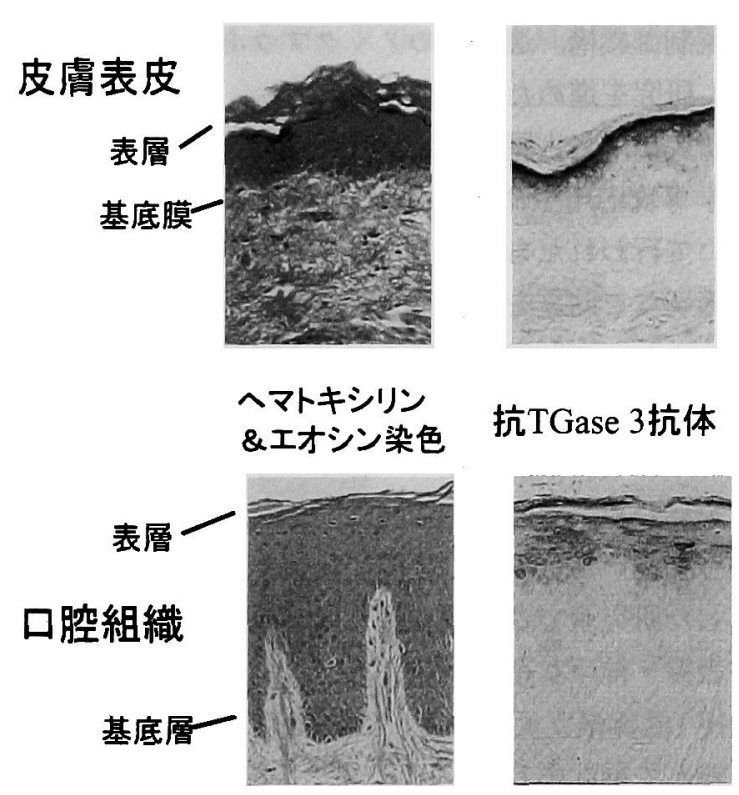

図 4 表皮型トランスグルタミナーゼ(TGase3) に対するモ ノクローナル抗体による組織染色（ヒト皮詹，口腔歯 茎)

の有無については不明である、脳, 神経系細胞では, RNA が明確に存在するのに比して抗体で検出できるタンパク質 としての存在量が少なく, 今後解析の対象としたい.

実際にヒトの皮膚において TGase 3 が分化段階に伴 い，どのように発現するかを，モノクローナル抗体を作製 して検討した，実際にヒト皮㲊の組織を染色して調べたも のが図 4 である.この抗体が他のアイソザイムとは交差し ないことを確認のうえ，これを行ったところ顆粒層と呼ば れる，かなり分化後期の上ころに明確な発現が見られた。 今回, 図は省略するが, 表皮細胞の初代培養細胞を用いて,
細胞分化に伴う発現パターンを解析した．この細胞培養系 は, カルシゥムの培地濃度上昇により, 分化が開始される が, TGase の発現は予想どおり分化後期に発現しているこ とがわかった。

また口腔組織は皮膚表皮と並び，外界と接している組織 で表皮細胞とよく似た性質, 細胞内構造タンパク質を有し ている，そこで同様の解析を，口腔組織のうち歯茎につい ても行ってみたところ，ここにも TGase 3 の明確な染色 像が観察された。 これまで TGase 1, TGase 3 による表皮 細胞の強化に関する研究は皮虞中心になされてきた， 口腔 組織は食品と初めて接触する場所であり,この組織におい ては食品成分による防御機構の増強など生理効果を発揮す る機構が存在している可能性がある. 口腔組織内がどのよ うな防御機構を保つのか, 食品成分の影響を受けることは あるのか, などについて今後は TGase を含むタンパク質 性の機能分子の働きについて展開したいと考えている.

4. 真性粘菌のトランスグルタミナーゼに関する解 析 ${ }^{28)}$

先に述べたように，皮膚表層は，TGase の架橋したタン パク質で強固な構造を形作り, 外界からの物理的, 化学的 攻撃に対応している.この概念をさらに下等生物にまで広 げて今後 TGase を研究していきたいと考えている. 真性 粘菌という生物は, 土壤などに住むアメーバの一種で, 多 様な生活環を有しており, 細胞運動などの解析に用いられ てきた．この生物にす TGase としての酵素活性が存在し ており，これまでの報告から，この生物が傷害を受けたと きに活性が上昇するということが知られていた299. 


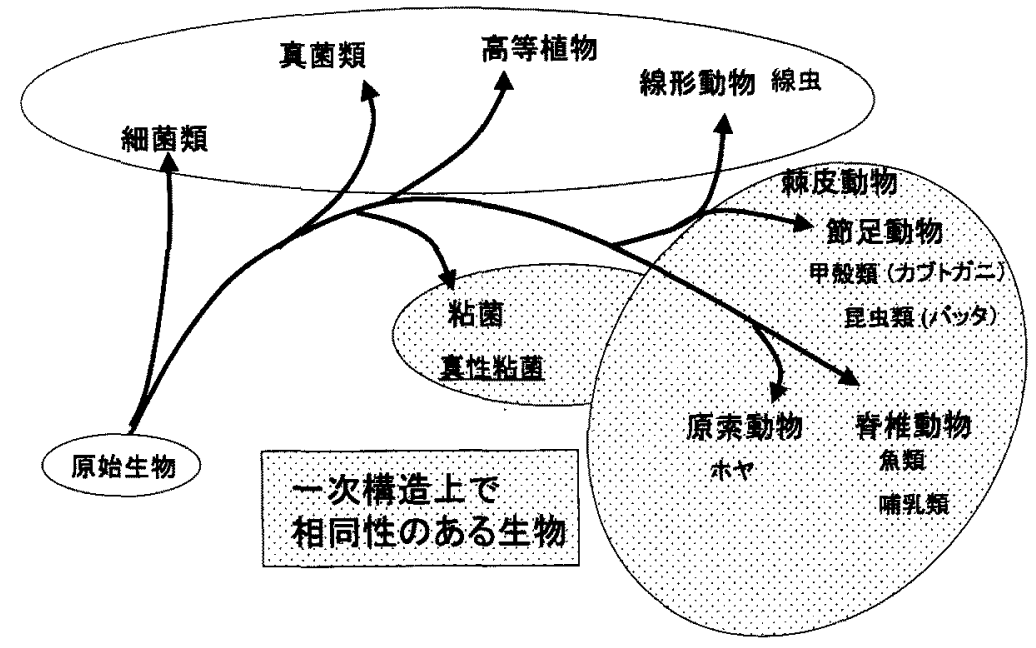

図 5 各種生物の進化に伴うトランスグルタミナーゼ遗伝子の多様性 哺乳類のタイプのむの以外については，互いに明確な相同性は見られない。

この真性粘菌のTGaseについて䣼素学的な性質は明ら かになっていたが，遺伝子単離や構造上の情報解析は明ら かにされていなかった。この生物での TGase の働きをモ デルとして，生体防御機構における生理作用を広く解析で きないかと考え，遺伝子のクローニングを試みた，精製し た酵素の配列をもとに遗伝子をクローニングし，全アミ， 酸配列を明らかにした。

その結果, 高等動物 (哺乳類) のTGase 之構造が類似し ていることがわかった，このことは実は意外なことであっ た，先にも述べたように，植物，微生物にもTGase 活性は 存在し，いくつか遗伝子構造も明らかになっているが，全 く構造が異なるタンパク質がこれを担っている，また，真 性粘菌より進化上高等な線虫において屯, 高等動物の夕イ プの遗伝子は存在しないとされていたからである゙0).これ まではカブトガニなどの節足動物が哺乳類の TGase と相 同性をあつ最む下等な生き物であったが, 現在のところ筆 者らのクローニングした真性粘菌のものが最す下等である ことになる。近年作製された哺乳類の TGase 2 (組織型) のノックアウトマウスは個体に明確な表現型が現れない31) (apoptosis した細胞への食作用, 傷害修復に支障が出ると いう発表はある)。これはアイソザイムによる redundancy（代替効果）のせいであると考えられるが，このよ うな下等な生物を用いることによって，TGase のさらなる 未知機能の検索が可能であろうと考えている.

本来の目的である生体防御機構については，まだ検討の 段階であるが，組換えタンパク質を抗原にして作製した抗 体を用いて，真性粘菌トランスグルタミナーゼの細胞内分 布を調べたところ, 細胞の表層部分に局在しており, 上記 の傷害修復にかかわっている可能性が示された，今後実際
の傷害時の活性発現制御之架橋反応の実体, life cycleて の発現制御機構，遺伝子のノックアウト個体の解析などを 行い，研究を進めたい上考えている。

本研究は, 名古屋大学大学院生命農学研究科応用分子生 命科学專攻応用生命化学講座 (分子細胞制御学研究分野) において行われたものであります。本研究の遂行において 終始適切なご助言を晹りました牧 正敏教授に感謝いたし ます。また，ご助言や試料の提供を睗りました伊倉宏司先 生（京都工芸繊維大学教授）に感謝いたします。山西清文 先生 (京都附立医科大学), 中村彰男先生 (群馬大学医学 部）をはじめ，本研究にご協力いただいたすべての方々に 心から感謝いたします。最後になりましたが、これまでに 所属した研究室でご指導を睗りました，千葉英雄京都大学 名誉教授・神戸女子大学名誉教授, 佐々木隆造京都大学名 誉教授 (滋賀県立大学教授), 塚越規弘名古屋大学大学院教 授に謹んで御礼申し上げます。

1) C. S. Greenberg, P. J. Birckbichler, and R. H. Rice: FASEB J., 5, 3071-3077 (1991).

2)小嶋聡一, 一瀬白帝: “細胞工学”, 第 18 巻, 秀潤社, 1999 pp. 1030-1038.

3) T.F. Slaughter, K.E. Achyuthan, T.S. Lai, and C.S. Greenberg: Anal. Biochem., 205, 166-171 (1992).

4) Z. Nemes, L. N. Marekov, L. Fesus, and P. M. Steinert: Proc. Natl. Acad. Sci. U.S.A., 96, 8402-8407 (1999).

5）留津欣也, 梅田幸一, 丹尾式希, 本木正雄: バイオサイエン スとバイオインダストリー, 60, 11-16 (2002).

6) P. Grenard, M. K. Bates, and D. Aeschlimann: J. Biol. Chem., 276, 33066-33078 (2001).

7) A. Ichinose, R. E. Bottenus, and E. W. Davie: J. Biol. Chem., 265, 13411-13414 (1990).

8) H. Nakaoka, D. M. Perez, J. Baek, T. Das, A. Husain, K. Misono, M.-J. Im, and R. M. Graham: Science, 264, 15931596 (1994). 
9) S. S. Akimov, D. Krylov, L. F. Fleischman, and A. M. Belkin: J. Cell Biol., 148, 825-38 (2000).

10) S. Y. Kim, T. M. Jeitner, and P. M. Steinert: Neurochem. Int., 40, 85-103 (2002).

11) A. Kalinin, L. N. Marekov, and P. M. Steinert: J. Cell Sci., 114, 3069-3070 (2001).

12) G. Melino, E. Candi, and P. M. Steinert: Methods Enzymol., 322, 433-473 (2000).

13) H. C. Kim, W. W. Idler, I.-G. Kim, J. H. Han, S. I. Chung, and P. M. Steinert: J. Biol. Chem., 266, 536-539 (1991).

14) P. M. Steinert, S.-I. Chung, and S.-Y. Kim: Biochem. Biophys. Res. Commun., 221, 101-106 (1996).

15) H. C. Kim, M. S. Lewis, J. J. Gorman, S. C. Park, J. E. Girard, J.E. Folk, and S.-I. Chung: J. Biol. Chem., 265, 21971-21978 (1990).

16) I. J. Kim, J. J. Gorman, S. C. Park, S. I. Chung, and P. M. Steinert: J. Biol. Chem., 268, 12682-12690 (1993).

17) C. D. Richardson: "Baculovirus Expression Protools," Human Press, Totowa, New Jersey, 1995.

18) K. Hitomi, A. Yokoyama, and M. Maki: Biosci. Biotechnol. Biochem., 62, 136-141 (1998).

19) K. Hitomi, Y. Uchiyama, I. Okubo, M. Kunimatsu, M. Sasaki, and M. Maki: Biochem. Biophys. Res. Commun., 246, 681-685 (1998).

20) K. Hitomi, S. Kanehiro, K. Ikura, and M. Maki: J. Biochem
(Tokyo), 125, 1048-1054 (1999).

21) K. Hitomi, Y. Yamagiwa, K. Ikura, K. Yamanishi, and M. Maki: Biosci. Biotechnol. Biochem., 64, 2128-2137 (2000).

22) B. Ahvazi, H. C. Kim, S.-H. Kee, Z. Nemes, and P. M. Steinert: EMBO J., 21, 2055-2067 (2000).

23) K. Hitomi, K. Ikura, and M. Maki: Biosci. Biotechnol. Biochem., 64, 657-659 (2000).

24) K. Hitomi, Y. Horio, K. Ikura, and M. Maki: Int. J. Biochem. \& Cell Biol., 33, 491-498 (2001).

25) K. Hitomi, R. B. Presland, T. Nakayama, P. Fleckman, B. A. Dale, and M. Maki: submitted.

26) T. Hiiragi, H. Sasaki, A. Nagafuchi, H. Sabe, S. C. Shen, M. Matsuki, K. Yamanishi, and S. Tsukita: J. Biol. Chem., 274, 34148-34154 (1999).

27) S.-Y. Kim, P. Grant, I.-H. Lee, H. C. Pant, and P. M. Steinert: J. Biol. Chem., 274, 30715-30721 (1999).

28) F. Wada, A. Nakamura, T. Masutani, K. Ikura, M. Maki, and K. Hitomi: Eur. J. Biochem., 269, 3451-3460 (2002).

29) J. Mottahedeh and R. Marsh: J. Biol. Chem., 273, 2988829895 (1998).

30) S. Natuska, R. Takubo, R. Seki, and K. Ikura: J. Biochem. (Tokyo), 130, 731-735 (2001).

31) V. D. Laurenzi and G. Melino: Mol. Cell Biol., 21, 148-155 (2001).

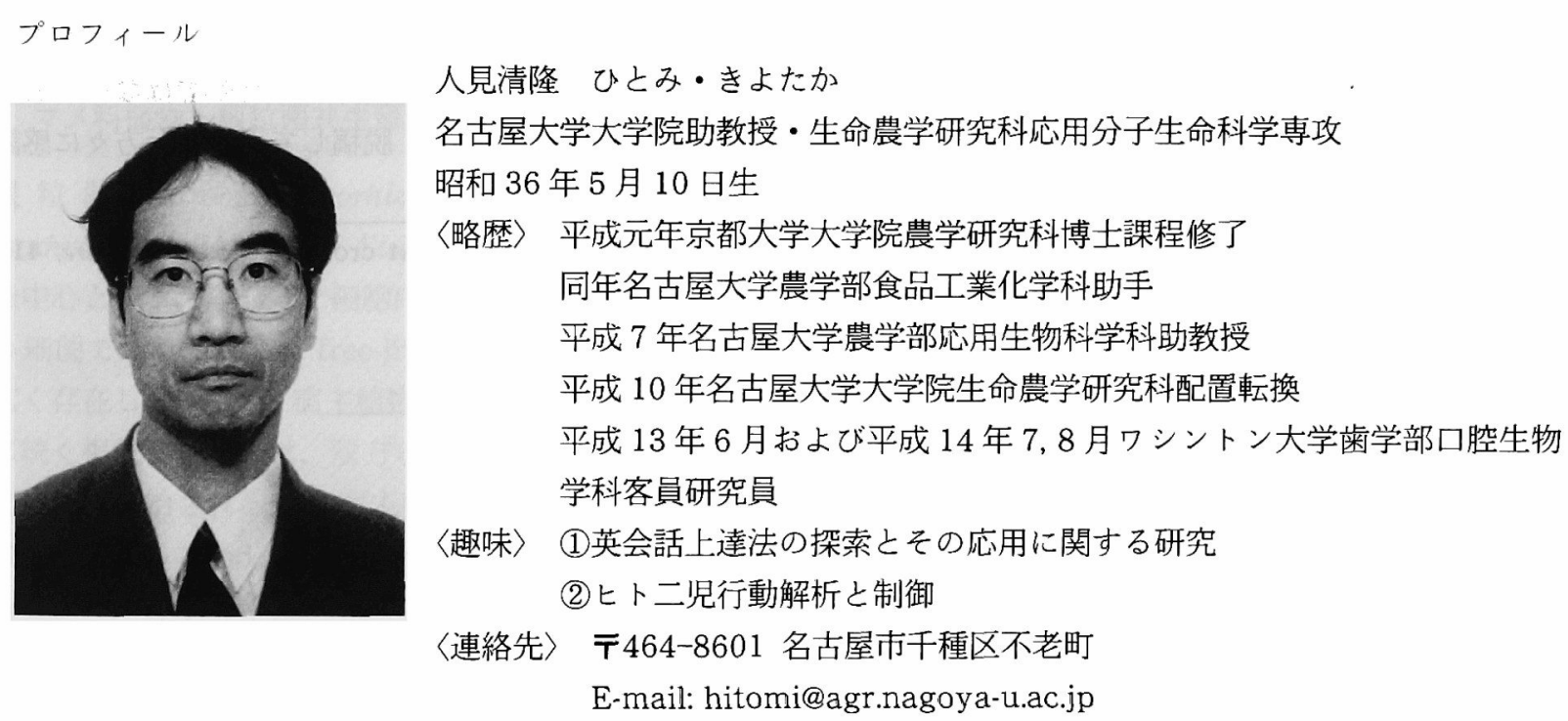

